Journal of Business School
$2019,2(6): 1-20$
DOI: $10.26677 / \mathrm{TR} 1010.2019 .140$
Journal Homepage: https://www.journalbusiness.org

\title{
Perception of Financial Variants of Multilevel Marketing Strategy And Growth of Network Marketing Companies in Nigeria
}

\author{
Seun Oladele \\ Bowen University, Iwo Osun State, seun.oladele2015@gmail.com \\ Johnson Laosebikan \\ Bowen University, Iwo Osun State
}

\begin{abstract}
The intense pressure on the Nigerian economy given the recent economic downturn has driven many Nigerians including entrepreneurs into multilevel marketing (MLM) schemes. Network marketing firms have in turn taken advantage of the economic situation to increase their activities in the Nation. Yet implication of this developed is yet to be explored in research. As such this study sought assess the relationship between financial factors (compensation and entry fees) in MLM strategy and motivation of Nigerian network entrepreneurs and determine the extent to which financial variants in MLM strategy affect growth of new NMOs in Nigeria The study was a survey of 202 MLM entrepreneurs of Swissgolden, AIM Global and Longrich using googleforms online survey. Data obtained were analysed using descriptive (mean and standard deviation) and inferential statistics (correlation and regression analysis). The study revealed low success rate among entrepreneurs participating in MLM in Nigeria. The study found significant relationship between the financial variants and motivation to join MLM $(\mathrm{r}=0.328, \mathrm{P}<0.05)$. Findings show that the reward system as a motivation to join MLM accounted for $36.2 \%$ variations in the growth potential of MLM while the entry fees accounted for $25.6 \%$. The study recommended that entrepreneurs take due care in selecting MLM they sign up with. Companies using MLM to promote their products should also design suitable compensation plans as well as incentivize entrepreneurs for actual sale of products rather than recruitment.
\end{abstract}

Keywords: Multilevel marketing, Network entrepreneurs, Financial factors, reward system, entry fees, Nigeria

\section{Introduction}

The increasing rate and pace of competition in the global market over the years has driven many companies to scout for new markets and create demands for their products as well as adopt new marketing strategies to penetrate the international market (Rezvani, Ghahramani, and Haddadi, 2017). Akinyi (2008) regarded this as a paradigm shift from the conventional reactive strategy. In the business world today, an important business decision when introducing new products or expanding existing products into new markets is the appropriate 
"marketing strategy" to adopt that would be profitable, cost effective and ultimately deliver competitive edge. One of the marketing strategies gaining prominence in the global business environment today is the "Multilevel Marketing Strategy" (MLM). MLM strategy lends itself to organizations as it presents expansion opportunities into international market, converts fixed cost to variable cost, bypasses middlemen and shifts major marketing activities to the entrepreneurs.

Since the early 1940s, the MLM strategy has been used by companies such as Oriflame, Nutrilite Food Supplement, American way (Amway) company, Herbalife, Shaklee and Mary Kay and since then Multilevel Marketing has been growing especially in the US, Philippines, China, India and other countries. Notable global growth was experienced in the 1990s. Malaysia, India and Pakistan and Bangladesh are regarded as some of the largest markets where MLM companies have operations. In Malaysia alone there are about 800 MLM companies operating. As at 1999, about $79 \%$ of direct selling companies in the US were MLM companies and they accounted for about 70-72\% (\$16.8billion) of aggregate sales (Khare and Verma, 2016a). Tamang (2008) reported that over 13million people in the US worked in the MLM industry, while Wigren (2017) reported over 103million in the world. In the 1950's, MLM model changed the nature of direct selling by adding what Keep and Vander Nat (2014) termed as "business opportunity".

Aggarwal and Kumar (2014, p.76) defined MLM to mean "a system for selling goods or services through a network of distributors". MLM connects the producer directly to the end users hence making buyers to become sellers in return for compensation or bonus. In this study, Multilevel Marketing (MLM) and Network Marketing (NM) is used interchangeably to mean the same thing. Network marketers/distributors have been represented by different scholars to be independent business owners (IBO) independent representatives, independent contractors or small business owners (Dai, Teo, and Wang, 2007); independent product consultants (Friberg, 2008) salespeople, independent distributors (Akinyi, 2008; Bogdan and Aron-Axel, 2013; Keep and Vander Nat, 2014); partners, multilevel marketers (MLMers) (Aggarwal and Kumar, 2014); entrepreneurs (Wigren, 2017). In this study, network marketers were described as entrepreneurs.

The MLM strategy comprises certain financial components germane to the success of any MLM business; compensation plan (Coughlan and Grayson, 1998) and upfront fees/registration fees/start-up capital (Droney, 2015). The antecedents are further grouped as financial factors in MLM strategy. Evidence abounds that the Nigerian market is still new to the general concept of MLM as a form of marketing relative to other western countries however NMOs activities have not gone unnoticed (Effiom and Effiong, 2015). Recently, Nigeria has recorded the influx of various MLM companies (Tepede, 2011). The development of MLM also was accompanied by invasion of pyramid schemes and ponzi schemes following the order of India, Malaysia, China and America. Gbadeyan and Olorunleke (2014) asserts that the expansion into Nigeria is likely due to market saturation in the home market. The similarity in operations of Ponzi and MLM gave rise to controversy about the legitimacy of MLM. This has created serious challenges for many companies adopting this strategy to promote their products/services hence the need for research to clarify this knowledge gap.

Failla (1996) averred that though MLM is one of the fastest growing industries it still remains the least understood. According to Aggarwal and Kumar (2014), in modern commerce MLM is one of the most polemic industries. Absence of accessible publications in the area has further contributed to the polarization and misconception (Oksanen, 1999; Bogdan and Aron-Axel, 2013) which has implication for companies introducing new or expanding existing products into the market using the MLM model hence the need for clarification. 


\section{Research Objectives}

The general objective of the study is to examine the behavioural pattern of Nigerian customers towards multilevel marketing strategy and the growth implications for NMOS, while the specific objectives are to

i. assess the relationship between financial factors in MLM strategy and motivation of Nigerian network entrepreneurs;

ii. determine the extent to which financial motivational factors in MLM strategy affect growth of new NMOs in Nigeria.

\section{Research Hypotheses}

In this study, four hypotheses are postulated and stated in their null form. They are as follows:

Hoii: There is no significant relationship between financial factors in MLM strategy and motivation of Nigerian network entrepreneurs.

$\mathrm{H}_{0 \mathrm{iv}}$ : Variations in financial factors in MLM strategy do not statistically account for significant variation in growth of new NMOs.

\section{Literature Review}

\subsection{Concept of Multilevel Marketing (MLM)}

Direct selling is a very old model of doing business and is considered a "vehicle for marketing to consumers or end buyers" (Keun, 2004, p.11). Jain, Singla, and Shashi (2015) pointed out that direct selling comprises single level marketing and multilevel marketing. The term MLM is also known as network marketing (Failla, 1996; Oksanen, 1999; Koehn, 2001; Akinyi, 2008; Yen, Chen and Chen, 2008; Koroth and Sarada, 2012; Bogdan and Aron-Axel, 2013; Aggarwal and Kumar, 2014; Keep and Vander Nat, 2014); multi-layer marketing (Rezvani et al., 2017). The definitions of MLM are widely varied as the number of scholars that has written about the concept (Bittnerova, 2015). Capturing the whole essence of multilevel marketing has been elusive and inconclusive in research. The complexity and controversy over the concept of MLM has been since the 90 's and this is basically driven by the misinterpretations, misconception, inaccurate conceptualization of the phenomenon which has also impaired research work in this area (Oksanen, 1999; Aggarwal and Kumar, 2014).

There is however wide consensus as to MLM being a form of direct selling (Oksanen, 1999; Vander Nat and Keep, 2002; Constantin, 2009; Charoenrungsirri and Oonsuphab, 2010; Keep and Vander Nat, 2014; Jain et al., 2015; Franco and Gonzalez-perez, 2016), though, Failla (1996) and Bogdan and Aron-Axel (2013) argue that viewing MLM as a form of direct selling is a misinterpretation. The basis of their argument was that direct selling requires the marketer to be employed as a representative of the company whose product he is selling unlike in MLM where the entrepreneur is independent and not legally employed by the company. Gbadeyan and Olorunleke (2014) describes this as "working for the company and not with the company". Also, in direct selling, a marketer is paid for only his sales and cannot be allowed to build his network of entrepreneurs like in MLM and each marketer in direct selling works for the benefit of the company and not for himself as in the case of MLM. However, there are four levels of marketing channels (Adetayo, 2012) namely: direct channel; one level channel; two levels channel; three levels channel. The channel most similar to the MLM model is the direct level channel which is also called the direct marketing channel and as such this study will treat MLM as a form of direct selling. 
The MLM phenomenon has been captured from different perspectives by different scholars. To Oksanen (1999), MLM is a legitimate retail selling through social network contact; network of independent sales representatives selling products and services (Koehn, 2001; Tamang, 2008); moving product through independent entrepreneurs (Koroth, 2011); a form of consumer marketing and compensation (Albaum and Peterson, 2011); method of distributing products (Koroth and Sarada, 2012; Aggarwal and Kumar, 2014); a franchise and hybrid method of distributing products and building sales network (Bogdan and Aron-Axel, 2013); business opportunity (Keep and Vander Nat, 2014); alternative to massive media advertising and sales promotion (Arya and Arya, 2014); alternative means of distribution (Gbadeyan and Olorunleke, 2014); network of master entrepreneurs recruiting other entrepreneurs into the network (Basil, Sunday, Anyadighibe, and Edward, 2014); a subset of the Direct Selling Industry (DSI) (Effiom and Effiong, 2015); revolves around recruiting theory and selling (Jain et al., 2015); a profession (Worre, 2015).

Network Marketing Organizations (NMOs) are primarily direct selling companies that depend heavily on personal selling (Choudhary and Haryana, 2013) or pay their agents (entrepreneurs) for buying products, selling products and recruiting downlines who also buy and sell products (Mathews, Manalel, and Zacharias, 2007). These entrepreneurs use "Word of Mouth" (WOM) to promote the companys' products. Abdussalam and Oyebode (2016) regarded WOM as the simplest, oldest and most natural form of marketing. MLM entails building an organization (Choudhary and Haryana, 2013) where lots of entrepreneurs only do little each (Failla, 1996). This is similar to the concept of synergy well expressed in the words of Paul Getty "it is better to make one percent of 100 people's effort than 100\% of your own efforts" (Vahidi, 2016). Bloch (1996) referred to the commission paid to entrepreneurs in MLM as "the big drawcard".

This was supported by the work of (Makni, 2015). This strategy was popularized by American Way Association (Amway) in the 1950's in the United States of America (Choudhary and Haryana, 2013) although Nutrilite is credited to be the first to adopt the strategy (Keun, 2004; Keep and Vander Nat, 2014; Khare and Verma, 2016b) and has been adopted by many firms subsequently (Khare and Verma, 2016b). Single level direct selling companies such as Avon and May Kay later joined the MLM club given the paradigm shift in the industry as well as the success of Amway using the MLM approach (See Table 1) (Yen et al., 2008; Keep and Vander Nat, 2014).

Table 1: MLM companies of the $20^{\text {th }}$ century

\begin{tabular}{|l|l|l|l|l|}
\hline S/n & Company & Products & Year & Headquarters \\
\hline 1. & Avon & Beauty Products & 1886 & USA \\
\hline 2. & Nutrilite & Vitamins and mineral and dietary supplements & 1934 & USA \\
\hline 3. & Tupperware & Home and beauty Products & 1948 & Florida \\
\hline 4. & GNLD & Health and Wellness Products & 1958 & USA \\
\hline 5. & Amway & Health, Beauty and home care Products & 1959 & USA \\
\hline 6. & Jeunique & Health and Beauty Products & 1959 & USA \\
\hline 7. & Mary Kay & Cosmetics & 1963 & USA \\
\hline 8. & Yanbal & Cosmetics & 1967 & Peru \\
\hline 9. & Belcorp & Cosmetics & 1968 & Peru \\
\hline 10. & Quorum & Apparels and Accessories & 1979 & Philippines \\
\hline 11. & Sunrider & $\begin{array}{l}\text { Food and beverages, Cosmetics, Household } \\
\text { products, Health products and Skin care }\end{array}$ & 1982 & USA \\
\hline 12. & Herbalife & Health, Fitness and Nutritional Products & 1983 & USA \\
\hline 13. & Advocare & Health and Fitness products and Personal Care & 1983 & USA \\
\hline
\end{tabular}




\begin{tabular}{|l|l|l|l|l|}
\hline & & products & & \\
\hline 14. & NuSkin & Personal Care Products & 1984 & USA \\
\hline 15. & Melaleuca & Health and Wellness Products & 1985 & USA \\
\hline 16. & Neways & Health, Wellness and Beauty Products & 1987 & USA \\
\hline 17. & $\begin{array}{l}\text { Equinox } \\
\text { Int'l }\end{array}$ & Water and air filters, vitamins & 1991 & USA \\
\hline 18. & USANA & Nutritional Products & 1992 & USA \\
\hline 19. & Mannatech & $\begin{array}{l}\text { Glyconutrition products, wellness and personal } \\
\text { care products }\end{array}$ & 1994 & USA \\
\hline 20. & Oriflame & Beauty Products & 1997 & Sweden \\
\hline
\end{tabular}

Source: Compiled by Author

\subsection{MLM, Pyramid Schemes and Ponzi Schemes}

From various definitions, it has been established that the main component that differentiates MLM from traditional direct selling is that it pays entrepreneurs in Multilevels i.e. commissions on the entrepreneurs' PV and commissions on GV of his downlines. As such, a legitimate MLM has a product that is moved from company to entrepreneur and then to consumers in many cases the entrepreneurs also consume the products internally. The concept of continual recruitment is however peculiar to MLM, Pyramid Schemes and Ponzi schemes. The survival of the three concepts depends largely on the ability of the members to recruit more members so as to expand the network. Friberg (2008) held that without recruitment there would be no network. This is what Vahidi (2016) called "people power". However the main difference between pyramid schemes and MLM model is that pyramid is predominantly centered on recruitment i.e. pays for the mere recruiting of new members without additional product or service (Bittnerova, 2015). This is called "business income". While MLM compensation are largely funded on direct and indirect retail commission (Vander Nat and Keep, 2002).

The growth of MLM birth Pyramid schemes (Keep and Vander Nat, 2014) requiring entrepreneurs to pay huge registration fee with a promise that same would be quickly returned with the expansion of the network (Bogdan and Aron-Axel, 2013). In 1973 pyramid sales was banned in Great Britain (Bogdan and Aron-Axel, 2013). The illegality of pyramid schemes as opposed to legitimate MLM is the inability to actually distribute products. Bogdan and AronAxel (2013) called this an "illegal organization of sales".

Keep and Vander Nat (2014) iterated that a pyramid scheme strives on recurrent recruitment as a mechanism for producing compensation for members. In a pyramid scheme, a sponsor does not get paid based on his productivity but by virtue of his position in the organization. The employees below do most of the work and yet do not make as much as those above him. In the structure, the owner makes bulk of the money by virtue of his position.

Keep and Vander Nat (2014) identified that there are Non-product based pyramid schemes that are simple transfer of wealth from one member to another. However similar this is, Keep and Vander Nat (2014) distinguished non-product based pyramid schemes from Ponzi schemes. According to Keep and Vander Nat (2014), Ponzi schemes strives on voluntary investments of new entrants to fund the investment returns paid to earlier entrants while a pyramid scheme incentivizes members to recruit others. The term Ponzi is named after Luigi Ponzi who celebrated the birth of the scheme (Gbadeyan and Olorunleke, 2014). Ponzi scheme is popularly called peer-to-peer donation in Nigeria. Pyramid and Ponzi schemes have prospered and as expected swindled so many people across countries. Notable among them is Nigeria. Most Albanians in 1997, lost their life's savings to two Ponzi schemes (Vander Nat and Keep, 2002). 
MMM was the most popular Ponzi scheme that defrauded millions of Nigerians between year 2016 and 2017. Save for MLM, pyramid schemes and Ponzi schemes are considered illegal, fraudulent and unethical (Bloch, 1996; Koehn, 2001; Muncy, 2004; Taylor, 2011; Rani and Kumar, 2013; Khare and Verma, 2016a). In lieu of the polarization that exist among these phenomenon, government regulators and other concerned citizens warily scrutinize MLM (Legara, Monterola, Juanico, Litong-palima and Saloma, 2008).

From evidences gathered, most Ponzi schemes in Nigeria are reincarnation of previous ones that have crashed. They change their names but maintain the same modus operandi to rob more Nigerians of their money. Most Ponzi schemes now resort to using WhatsApp groups to operate, and they have a no-advert rule, compulsory recycling, and compulsory sharing of testimony. Obviously, the success of Ponzi just like in the case of MLM depends largely on the recruiting of new members that will pledge funds $(\mathrm{PH})$ to other members. The one who pledges is then paired with another member who requests for funds. The member who PHed is then required to fulfil his financial obligations to the paired member within a stipulated time. The transaction is then approved by the member who GHed and then the one who PHed is cleared of his obligations and can GH in subsequent time.

\subsection{Compensation Plan/ Reward System in MLM}

Albaum and Peterson (2011) noted that the compensation plan of typical MLM company is complex and vary (Vanger Nat and Keep, 2002). "Some plans allow recruits to "break away" from their sponsors eventually. Others require sponsors to "pass" one/two recruits called "upline" to their direct supervisor" (Vander Nat and Keep, 2002, p.140). The compensation for entrepreneurs mainly comes from three sources: discounts on their wholesale purchases which they may as well consume personally or resell at a profit. The mark-up is usually $40-50 \%$ (Coughlan and Grayson, 1998); commissions on his own sales including those that he consumes personally called personal volume (PV); commission on the group sales/volume (GV) of the entrepreneurs downline and mark-ups on personal sales to customers outside the network (Albaum and Peterson, 2011). Coughlan and Grayson (1998) regarded the third compensation as the most complex compensation of an NMO. This third category is actually what makes NM multilevel, where sponsors are paid commissions for the purchase or sales made by their recruits called "downlines".

Lee and Loi (2016) however classified the compensation into two: sales commission and referral bonuses. From the example in figure 1, Seun recruits Femi, Sola and Deola. Sola who was the first downline for Seun among others and as such Seun gets paid commissions on the sales efforts of Sola. In the same vein, Tolu, Temi and Tayo were directly recruited by Sola (For Seun, Femi, Sola and Deola are his first level downlines, while Tolu, Temi and Tayo are on Seuns' second level but on Solas' first level) and as such, Sola gets paid for the successful sales effort of her downlines in level 1 and so does Seun for level 1 and 2. Many MLM restrict the number of levels to which Upline get paid but it is not uncommon to find MLMs who pay commissions up to the 6-9th level of an entrepreneurs' organization. 


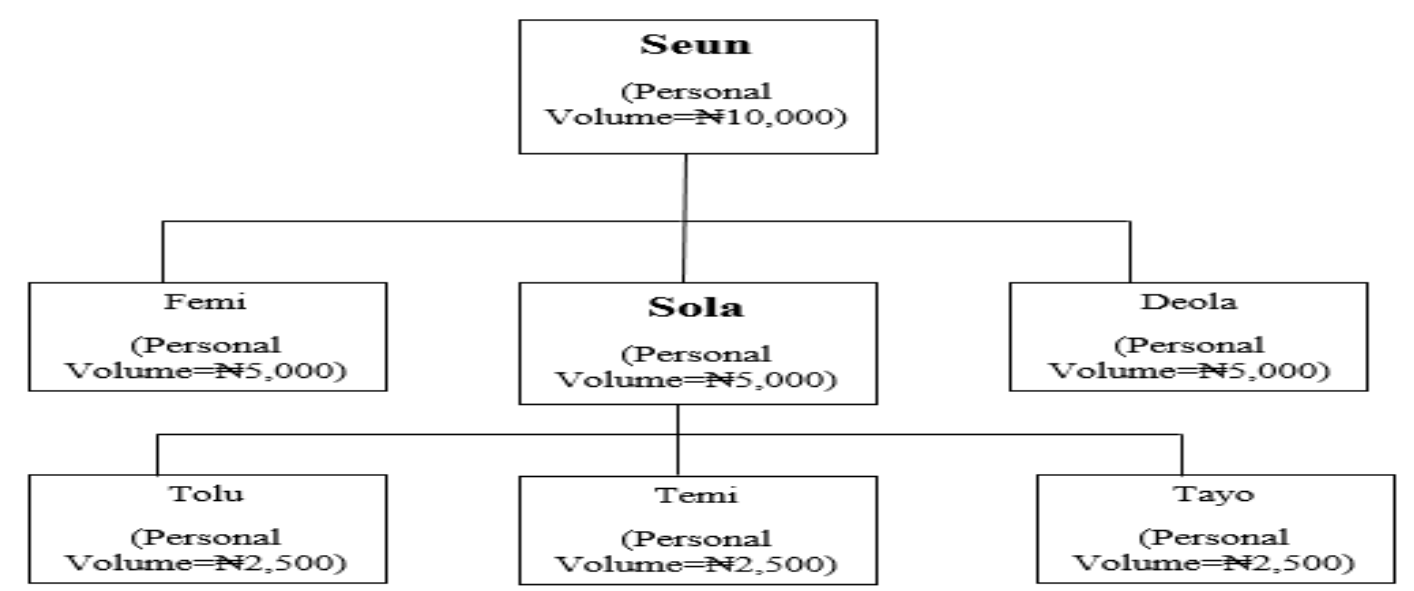

Commission Schedule

\begin{tabular}{|c|c|}
\hline Volume & Commission rate \\
\hline \#1- $¥ 4999$ & $3 \%$ \\
\hline ¥5000- 9999 & $5 \%$ \\
\hline$\$ 10,000$ - Above & $7 \%$ \\
\hline
\end{tabular}

Figure 2: Example of a typical MLM compensation plan chart

Source: Researcher (2017)

In most NMOs, the rate of commission increases in line with the group volume. The group volume is an aggregate of all personal volumes including all sales generated by each member in an entrepreneurs' network. Typical of most NMOs, the net commission rate of an entrepreneur on the PV of his downline is the difference between the entrepreneurs' commission rate and the rate of his downline commission (Coughlan and Grayson, 1998). From figure 1, Seun sold goods worth $\$ 10,000$, Femi, Sola and Deola sold $\$ 5,000$ worth of products each while Tolu, Temi and Tayo sold $\$ 2,500$ each. Here, Seun's GV is $\$ 32,500$ and his commission is based on the GV. Applying the simple Commission schedule in figure 1, Seun earns $7 \%$ of his GV ( $\$ 2,275)$. From the 7\%, Sola gets $5 \%$ ( $\$ 625$ ) for his GV and the other two downlines (Femi and Deola) get $\$ 250$ each (5\% of their PV of $\$ 5,000$ ). From Sola's commission, 3\% (\$75) commission is deducted for each of his downlines on their PV. Thus, Tolu, Temi and Tayo make net commission of A75, Sola $\$ 400$ and Seun $\$ 1,150$. In addition to this, each of the entrepreneur gets wholesale-retail markups on their PV (Coughlan and Grayson, 1998).

Scholars have identified two main types of commission system: Unilevel and Binary commission system (Legara et al., 2008; Bogdan and Aron-Axel, 2013; Effiom and Effiong, 2015; Khare and Verma, 2016a)

\subsection{Registration/Upfront Fees in MLM}

The pyramid test proposes that the cost of entry or registering as a partner or entrepreneur of an MLM company must not be unreasonably high (Albaum and Peterson, 2011). This parameter for judging a legitimate MLM company has been flawed by scholars who feel at what rate is the entry cost considered too high or appropriate? Various MLM in Nigeria vary in terms of cost required to be paid to become an entrepreneur. Swissgolden for example has a basic plan that cost $£ 75$. This was done to accommodate people who were willing but unable to afford the 
previous $220 £$ to be part of the MLM program. Following the introduction of the Swissgolden Start program package that cost only $£ 75$, many Nigerians jumped at the opportunity as it was more affordable than the $£ 220$ package. Another example is Alliance Global, for a half hamper (associate package B) package in Alliance in motion global, it cost about $\$ 38,000$ (worth N41,860).

It cannot be avoided that the entry cost for many Ponzi schemes have deceived so many Nigerians. It is common to find schemes that require as low as $\$ 1000$ to register and promises $100 \%, 200 \%, 300 \%$ and so on return in less than a week. Over 200 schemes have been identified in Nigeria. Many Nigerians have been found to opt for such seemingly "lower risk" ventures. While they shy away from legitimate MLM claiming the financial commitment is high and it is uncertain they can sell or market hence they don't want their capital tied down. It becomes imperative therefore for MLM companies to know how the target market feels about their fee as this affects the motivation of the prospects to become entrepreneurs. With this understanding, entrepreneurs can device plans to change customers' attitude by implication behaviour towards MLM.

The role of exchange rate cannot be displaced also. As at April 2017 in Nigeria $£ 75$ for Swissgolden is about $\$ 46,000$.

\subsection{Perception and Motivation}

Perception is closely related to attitude (Pickens, 2005; Gbadeyan and Olorunleke, 2014; Kalra, Kondepudi and Sridharan, 2016); and a mental phenomenon (Fish, 2010). Perception relates to the process of producing meaningful experience about a product or an organization by interpreting and organizing sensation (Pickens, 2005). The interpretation or feeling may however be real or different from reality (Allport, 1935; Pickens, 2005; Kondalkar, 2007). Fish (2010) viewed perception as an acquisition of beliefs. Kalra et al (2016) expressed perception as the most influential factor that shapes attitude towards a phenomenon. By implication, the success of the MLM industry is contingent in part on the perception and motivation of the consumers (Joshi, 2014; Kalra et al., 2016). This is because the model revolves around people and how they feel about attributes of the model. The consumers actually make the system work. For example, to the extent which people are familiar with the system of MLM in Bulgaria, the perception has not been somewhat positive (Makni, 2015) similar to the findings of Joshi, (2014) in India, this surely in part impaired growth of MLM in those regions.

In Latin, the root word "motivation" means to "move" which basically indicates the study of action (Eccles and Wigfield, 2002). Motivation is a complex phenomenon and difficult to measure (Mubeen and Reid, 2006), a multidimensional construct (Peklaj and Levpuscek, 2006); second-order variable (Mubeen and Reid, 2006); cognitive element of attitude (Afzal and Ali, 2010); psychological process (Haider, Qureshi, Pirzada, and Shahzadi, 2015; Bittnerova, 2015). Motivation communicates factors or reasons underlying behaviour. It is termed an "inner force" (Mubeen and Reid, 2006; Reavis, 2014) influencing direction of thought, feeling and action towards a phenomenon (Miekina, 2012). The activities, energy exerted, action and behaviour of man strives on how motivated they are (Bittnerova, 2015). Motivation can be intrinsic and extrinsic (Mubeen and Reid, 2006; Haider et al., 2015); monetary or non-monetary, positive or negative (Miekina, 2012). This study focuses more on external forces/incentives (extrinsic factors) that motivates consumers to purchase, sell, and be associated from/to/with MLM in Nigeria. Intrinsic motivation is fuelled by personal gratification, interest, or want. Here, the participant or individual takes delight in doing the activity seeing it as an opportunity to explore his potential without much regard for the external reward (Eccles and Wigfield, 2002). 
Whereas extrinsic motivation is driven by re-inforcers. The individual does it clearly for the reward involved (Eccles and Wigfield, 2002; Haider et al., 2015). The reward could be financial or non-financial. It could also be due to pressure from friends and family. Extrinsic motivation has been noted to produce more results in short-term with less efforts (Chow and Yong, 2013) than intrinsic motivation. However, once the extrinsic incentives is removed, the individual stops being motivated and this is the edge of intrinsic motivation over extrinsic (Chow and Yong, 2013). People who are intrinsically motivated tend to perform better over a long period of time as their reasons for engagement is more internalized (Dai, Teo, and Wang, 1995). Eccles and Wigfield (2002) and Chow and Yong (2013) established that extrinsic incentives when too strong (Miekina, 2012) could be a deterrent to intrinsic motivation to perform an activity.

In the same vein, individuals can be certain they can perform an activity yet decline without a compelling reason to do so. In lieu, customer attitude/behaviour towards MLM/NMOs can be measured and their motivations for wanting or not wanting to be a part of MLM can be evaluated in terms of their feelings (positive or negative) and response to selected elements of the MLM program. Ong et al (2007) impressed that positive perception about MLM influences intention and eventual deliberate behaviour to participate in the program.

\subsection{Empirical Review \\ 4.6.1 Registration Fee and Motivation to Join MLM}

Gbadeyan and Olorunleke (2014) studied customer perception towards MLM in Ilorin, Nigeria focusing on three prominent MLM operating in Nigeria comprising Forever Living, GNLD and Tianshi. The study found that the small amount required to start the program was a major motivating factor to entrepreneurs in GNLD and forever living expressed that the start-up capital was a major difficulty that demotivates them from joining the program.

Albaum and Peterson (2011) pointed out in their qualitative study that legitimate MLMs do not charge typically high entry fees however, Jain et al (2015) discovered in a study on "motivational factors in MLM business: a confirmatory approach" that low investment alongside factors such as product quality, ease entry, extra money, freedom are the most effective variables that convince people to be a part of MLM. The study did not however emphasize the entry cost as an integral component of MLM which could have significant effect on prospects as well as entrepreneurs.

\subsubsection{Compensation Plan and Motivation to join MLM}

Many scholars have also agreed that reward system plays a significant role in entrepreneurs satisfaction and motivation to join MLM (Coughlan and Grayson, 1998; Lee and Loi, 2016; Lee, Lau ad Loi, 2016). Scholars have agreed that the financial promise motivates many to become networkers (Coughlan and Grayson, 1998; Lee and Loi, 2016; Lee et al., 2016).

Coughlan and Grayson (1998) took a critical look in the compensation plans, retail network growth and profitability of Network marketing organizations (NMOs) by calibrating a unique decision model of a retail NMO growth. Their study identified commissions and mark-ups on personal sales, net commission on personal sales of downlines are the common motivation incentives used by NMOs to motivate entrepreneurs. The study drew upon descriptive and prescriptive insights revealing how compensation among other parameters influence entrepreneurs' motivation, sales, growth and profit. The study concluded that it is important from the perspective of the entrepreneur to perceive the compensation plan and incentives provided by the NMOs as good in order to retain them in business and earn reasonable profit. 
Employing one-way analysis of variance, the study of Lee and Loi (2016) found that for entrepreneurs who earned less than RM1000 from MLM monthly exhibited less satisfaction than those who earned more. Gbadeyan and Olorunleke (2014) found that $54 \%$ of customers in Ilorin are motivated by the profit payment to members, percentage paid as commission and other auxiliary incentives and this was expressed more by members of Tianshi. The study of Ong et al (2007) in Malaysia on reasons why Malaysians join and stay on in MLM found that though incentives and financial benefits do not constitute the top three reasons why people join MLM, it is a major reason why they remain in the industry.

\section{Methods}

This study is a cross-sectional descriptive study and the survey method using the deductive approach and using quantitative research method common in business and management research (Otokiti, 2010). The population for this study comprises entrepreneurs in three selected MLM companies in Nigeria (Swissgolden, AIM Global and Longrich). These companies were purposively selected due to access to data and their relatively similar registration fees as well as year of establishment in Nigeria. Non-probability sampling (convenience sampling) was the sampling technique employed. Many studies (Ong et al., 2007; Koroth, 2011; Koroth and Sarada, 2012; Leng, 2015; Yin, 2015; Wigren, 2017) on MLM have employed non-probability sampling (convenience sampling) in carrying out their research given issues revolving around getting information as regards the population of study. Primary data was obtained from a sample of 202 network entrepreneurs were using a structured questionnaire. Sekeran (2003) added that in using an online survey, the number of respondents inclined to participate in the survey constitute the sample size. According to Wigren (2017) an online survey is suitable for a study such as this given that it allows reaching a wider percentage of people with minimal bias. The questionnaire comprised 21 questions and was administered via online platforms such as NMOs Whatsapp group chats and Facebook pages using a link (Link: https://goo.gl/forms/9ps5DxqeTsP1jbvC3) which was left online for a period of 8weeks. The hypotheses were tested using correlation and regression analyses.

\section{Findings and discussions}

The part presents and discusses the results from the questionnaire. Inferences from literature contents and implications are highlighted.

\subsection{Respondents general information}

6.1.1 Statistics on Sex of Respondents. About $60.2 \%$ of the respondents are male while $39.8 \%$ are female. Many studies have however reported more of female network marketers (Effiom and Effiong, 2015; Lee et al., 2016) but the result shows high participation of the male counterparts similar to the findings of Koroth and Sarada (2012).

6.1.2 Statistics on Age Brackets of Respondents. Less than half (45.5\%) of the respondents were between the ages of $24-29$ years, $22.8 \%$ were between the ages of $30-35$ years, $14.9 \%$ were between the ages of 18 -23years, $8.9 \%$ between $36-41$ years, $4.0 \%$ were between the ages of 42 $47 y e a r s, 3.5 \%$ were between the ages of $48-53$ years and only $0.5 \%$ was above 54 years of age. A higher percentage of network marketers can be said to be between the ages of 24 to 35years.

6.1.3 Statistics on respondents' years of experience in MLM. A higher percentage $49.0 \%$ of network entrepreneurs were less than a year old in the network marketing business (NMB), $43.1 \%$ of the respondents had between 1-5years experience in the business while (5.9\%) had spent between 610 years as network marketers, $1.5 \%$ and $0.5 \%$ had spent between $11-15$ years and above 20years as network marketers respectively. The implication is that there has been a recent influx of Nigerians into the NMB given the rapid influx of network marketing organizations (NMOs) in 
recent years, the economic downturn and the "business opportunity" network marketing promises is another factor.

6.1.4 Statistics on MLM affiliation. shows high participation of network marketers in Swissgolden representing $50.5 \%$ of the total responses. AIM Global network entrepreneurs constituted $26.2 \%$ of the respondents, while Longrich trails behind with $23.3 \%$ network marketers.

6.1.5 Statistics on respondents' monthly income from MLM. Most of the respondents that is $72.8 \%$ earned less than a $\$ 100,000$ per month from NMB, while $21.8 \%$ earned between a $\$ 100,000$ $\$ 500,000$ a month, $2.5 \%$ earned between $\$ 500,000-\$ 1,000,000$ a month, $2.0 \%$ ) and $1.0 \%$ earned between $\$ 1,000,000-\$ 2,000,000$ and above $\$ 2,000,000$ respectively. The relatively high differences in earning may be accounted for by the newness of most of the respondents into the business or support the claim of critics such as (Bloch, 1996; Koehn, 2001; Muncy, 2004; Taylor, 2011; Khare \& Verma, 2016a) arguing that 99\% of MLM participants lose money.

Table 2: Respondents' general information

\begin{tabular}{|c|c|c|}
\hline Variables & Frequency & Percentage (\%) \\
\hline \multicolumn{3}{|l|}{ Sex } \\
\hline Male & 122 & 60.4 \\
\hline Female & 80 & 39.6 \\
\hline Total & 202 & 100.0 \\
\hline \multicolumn{3}{|l|}{ Age Bracket } \\
\hline $18-23$ & 30 & 14.9 \\
\hline $24-29$ & 92 & 45.5 \\
\hline $30-35$ & 46 & 22.8 \\
\hline $36-41$ & 18 & 8.9 \\
\hline $42-47$ & 8 & 4.0 \\
\hline $48-53$ & 7 & 3.5 \\
\hline 54-Above & 1 & 0.5 \\
\hline Total & 202 & 100.0 \\
\hline \multicolumn{3}{|c|}{ Experience as a Marketer } \\
\hline Less than a year & 99 & 49.0 \\
\hline $1-5$ years & 87 & 43.1 \\
\hline 6-10Years & 12 & 5.9 \\
\hline 11-15years & 3 & 1.5 \\
\hline Above 20years & 1 & 0.5 \\
\hline Total & 202 & 100.0 \\
\hline \multicolumn{3}{|l|}{ MLM Affiliation } \\
\hline Swissgolden & 102 & 50.5 \\
\hline AIM Global & 53 & 26.2 \\
\hline Longrich & 47 & 23.3 \\
\hline Total & 202 & 100.0 \\
\hline \multicolumn{3}{|c|}{ Monthly Income from NM } \\
\hline Below $\$ 100,000$ & 147 & 72.8 \\
\hline$¥ 100,000-\$ 500,000$ & 44 & 21.8 \\
\hline$\$ 500,000-\$ 1,000,000$ & 5 & 2.5 \\
\hline$\aleph 1,000,000-\$ 2,000,000$ & 4 & 2.0 \\
\hline Above $¥ 2,000,000$ & 2 & 1.0 \\
\hline Total & 202 & 100.0 \\
\hline
\end{tabular}

Source: Survey (2017) 


\subsection{Indices on Financial Factors in MLM Strategy and Motivation of Nigerian Network Entrepreneurs}

Table 3 relates the opinion of the respondents as to whether certain financial factors such as entry fees and financial compensation motivated them to join network marketing or not. The results reveals that $33.2 \%$ and $42.1 \%$ of the respondents submitted strongly agree and agree respectively which attest their preference for MLM with low entry fee over those with relatively higher entry fees. Only $3.0 \%$ and $2.0 \%$ of the respondents disagreed and strongly disagreed respectively. In the same vein, a high percentage of the respondents, that is $50.0 \%$ for strongly agree and $36.1 \%$ for agree confirmed that there is high tendency for prospects to motivated to join MLMs with low entry fees than those with high registration fee, while only $3.5 \%$ respondents disagreed, opining that it may not hold true whereas $10.4 \%$ were uncertain about this assertion. By implication, variations in registration fees may account for reasons why some join one NMO or the other. This may be true given the financial status of most Nigerians which may drive them to MLM with registration fees they can afford with minimal regard for the product or service offered.

About $47.5 \%$ and $42.1 \%$ respondents submitted strongly agree and agree respectively attesting that the system of financial compensation offered by NMOs influenced network entrepreneurs' preference of an NMO over another NMO while $2.0 \%$ and $1.5 \%$ disagreed and strongly disagreed respectively. This may account for why some network marketers move from one NMO to another. Similarly, $50.5 \%$ of the respondents strongly agreed and $37.6 \%$ agreed that NMOs with the best compensation plan tend to get more marketers to participate while few $(1.5 \%)$ disagreed. A grand mean score of 4.26 with a standard deviation of 0.809 indicates significant variation in responses tilting towards agreement.

\subsection{Indices on Financial Factors in MLM Strategy and Growth of NMOs in Nigeria}

Table 4 shows the perception of the respondents towards the implication financial factors in MLM strategy has on growth of NMOs in Nigeria. A high percentage of the respondents that is $34.2 \%$ for strongly agree and $44.6 \%$ for agree attested that the entry fee adopted by NMOs has growth implication for the NMO. Implying that NMOs with lower entry fee and those with higher fees may have different level of growth. However, 15.8\% remained undecided about the assertion while $4.0 \%$ disagreed and $1.5 \%$ strongly disagreed. In tandem, most of the respondents $80.7 \%$ (39.1\% strongly agreed and $41.6 \%$ agreed) submitted that motivation through financial compensation plan offered by their NMO has growth implication for the NMOs while $5.0 \%$ and $1.0 \%$ respectively disagreed and strongly disagreed whereas $13.4 \%$ held a neutral position. The standard deviation (0.892) shows relatively high tilting towards agreement. By implication, positive perception and motivation of financial factors are important for growth of NMOs. 
Journal of Business School, vol.2, issue.6, pp.1-20

Table 3: Financial Factors and Motivation of Nigerian network entrepreneurs

\begin{tabular}{|c|c|c|c|c|c|c|c|}
\hline Variables & SA(\%) & $\mathrm{A}(\%)$ & $\mathrm{U}(\%)$ & $D(\%)$ & $\operatorname{SD}(\%)$ & Mean & $\begin{array}{l}\text { Std } \\
\text { Dev }\end{array}$ \\
\hline $\begin{array}{l}\text { Low Entry Fee } \\
\text { Fees and Entry }\end{array}$ & $67(33.2)$ & $85(42.1)$ & $40(19.8)$ & $6(3)$ & $4(2)$ & 4.01 & 0.911 \\
\hline Tendency & 101(50) & $73(36.1)$ & $21(10.4)$ & $7(3.5)$ & - & 4.33 & 0.799 \\
\hline $\begin{array}{l}\text { Reward as } \\
\text { motivation } \\
\text { Reward and } \\
\text { Entry Tendency }\end{array}$ & $96(47.5)$ & $85(42.1)$ & $14(6.9)$ & $4(2)$ & $3(1.5)$ & 4.32 & 0.811 \\
\hline Grand Mean & $102(50.5)$ & $76(37.6)$ & $21(10.4)$ & $3(1.5)$ & - & $\begin{array}{l}4.38 \\
4.26\end{array}$ & $\begin{array}{l}0.718 \\
\mathbf{0 . 8 0 9}\end{array}$ \\
\hline
\end{tabular}

Note: $S A$, strongly agree; $A$, agree; $U$, undecided; $D$, disagree; $S D$, strongly disagree

Table 4: Financial factors and growth of NMOs

\begin{tabular}{|c|c|c|c|c|c|c|c|}
\hline Variables & SA(\%) & $A(\%)$ & $\mathrm{U}(\%)$ & $D(\%)$ & $\mathrm{SD}(\%)$ & Mean & $\begin{array}{l}\text { Std } \\
\text { Dev }\end{array}$ \\
\hline Fee and Growth & $69(34.2)$ & $90(44.6)$ & $32(15.8)$ & $8(4)$ & $3(1.5)$ & 4.06 & 0.890 \\
\hline Reward and & & & & & & & \\
\hline Growth & 79(39.1) & $84(41.6)$ & $27(13.4)$ & $10(5)$ & $2(1.0)$ & 4.13 & 0.894 \\
\hline Grand Mean & & & & & & 4.09 & 0.892 \\
\hline
\end{tabular}

Note: $S A$, strongly agree; $A$, agree; $U$, undecided; $D$, disagree; $S D$, strongly disagree

\subsection{Hypothesis Testing}

Correlation and regression analysis were used to test the hypotheses

6.4.1 Test of H01. H01 relates that there is no significant relationship between financial factors in MLM strategy and motivation of Nigerian network entrepreneurs. The analysis shows that at 0.05 level of significance, $r=0.328, \mathrm{P}=0.0001$ (2-tailed test) for the entry fee and motivation to join MLM. This means that since $p<0.05$, there is a positive relationship between the entry fee and motivation to join MLM. Similarly, the analysis on compensation plan and motivation to join MLM showed a significantly positive correlation with $\mathrm{r}=0.327 \mathrm{p}=0.0001$ at 0.05 level of significance (See Table 5). This indicates that a positive relationship exists $(\mathrm{P}<0.05)$. In a similar study by Coughlan and Grayson (1998) and Lee et al (2016), financial reward was reported to be a good motivation for joining MLM business with higher preference for affordable NMOs.

Table 5: Correlation results for Hypothesis 1

\begin{tabular}{|ll|r|r|r|r|}
\hline Entry Fee & Entry Fee & $\begin{array}{c}\text { Motivation to } \\
\text { join }\end{array}$ & $\begin{array}{c}\text { Reward } \\
\text { System }\end{array}$ & $\begin{array}{c}\text { Motivation to } \\
\text { join }\end{array}$ \\
\hline Correlation & 1 & $.328^{* *}$ & & \\
Sig. (2-tailed) & 202 & .000 & & \\
N & 202 & & \\
Pearson & $.328^{* *}$ & 1 & & \\
Motivation to Correlation & .000 & & & \\
join $\quad$ Sig. (2-tailed) & 202 & 202 & & \\
N & & & & 1 & \\
Rearson & & & &
\end{tabular}




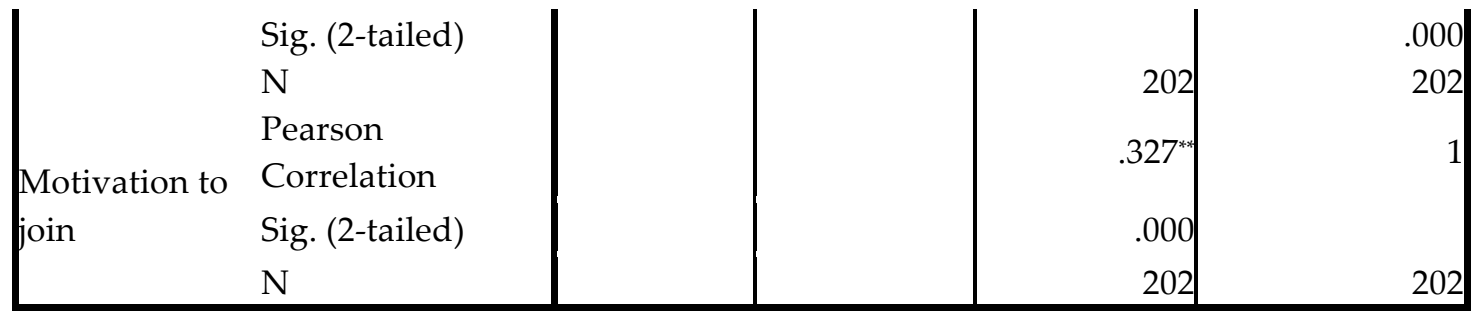

**. Correlation is significant at the 0.05 level (2-tailed).

6.4.2 Test of H02. H02 postulated that variations in financial factors in MLM strategy do not statistically account for significant variation in growth of new NMOs.

The model summary in Table 6 revealed that the extent to which the variance of growth of NMOs can be explained by the degree of motivation of the reward system is $10.5 \%$ (i.e. $R$ square $=0.105$ ). The ANOVA in Table 7 shows the Fcal as 23.417 at 0.05 level of significance. The reward system thus accounts for only about $10 \%$ of variations in growth of NMOs. The work of Ong et al (2007) in Malaysia on reasons why Malaysians join and stay on in MLM found that though incentives and financial benefits do not constitute the top three reasons why people join MLM, it is a major reason why they remain in the industry.

The coefficient analysis in Table 8 shows a simple model that expresses reward system impact on growth of NMOs. The model is mathematically shown below.

$\mathrm{Y}=\mathrm{A}+\mathrm{Bx}+\mu$, where $\mathrm{Y}$ is the growth of NMOs; $\mathrm{A}$ is the constant; $\mathrm{B}$ is the value of coefficient; $\mu$ is the error term. Therefore, GNMOs $=2.562+.362(\mathrm{RS})+.075$. This means that for every $100 \%$ growth of an NMO, reward system contributed $36.2 \%$.

Table 6: Model summary of reward system and growth of NMOs

\begin{tabular}{|l|r|r|r|r|}
\hline Model & \multicolumn{1}{|c|}{$\mathrm{R}$} & R Square & \multicolumn{1}{c|}{$\begin{array}{c}\text { Adjusted R } \\
\text { Square }\end{array}$} & $\begin{array}{c}\text { Std. Error of the } \\
\text { Estimate }\end{array}$ \\
\hline 1 & $.324^{\mathrm{a}}$ & .105 & .100 & .848 \\
\hline
\end{tabular}

a. Predictors: (Constant), Reward System

Table 7: ANOVA results for reward system and growth of NMOs

\begin{tabular}{|c|c|c|c|c|c|}
\hline Model & Sum of Squares & $\mathrm{df}$ & Mean Square & $\mathrm{F}$ & Sig. \\
\hline Regression & 16.839 & 1 & 16.839 & 23.417 & $.000^{\mathrm{b}}$ \\
\hline Residual & 143.815 & 200 & .719 & & \\
\hline Total & 160.653 & 201 & & & \\
\hline
\end{tabular}

a. Dependent Variable: Growth of NMOs

b. Predictors: (Constant), Reward system 
Table 8: Coefficient results for reward system and growth of NMOs

\begin{tabular}{|c|c|c|c|c|c|}
\hline \multirow[t]{2}{*}{ Model } & \multicolumn{2}{|c|}{ Unstandardized Coefficients } & \multirow{2}{*}{$\begin{array}{c}\begin{array}{c}\text { Standardized } \\
\text { Coefficients }\end{array} \\
\text { Beta }\end{array}$} & \multirow[t]{2}{*}{$\mathrm{t}$} & \multirow[t]{2}{*}{ Sig. } \\
\hline & B & Std. Error & & & \\
\hline (Constant) & 2.562 & .329 & & 7.783 & .000 \\
\hline $\begin{array}{l}\text { Reward } \\
\text { System }\end{array}$ & .362 & .075 & .324 & 4.839 & .000 \\
\hline
\end{tabular}

a. Dependent Variable: Growth of NMOs

The model summary in Table 9 revealed that the extent to which the variance of growth of NMOs can be explained by the degree of motivation of the entry fee is $6.9 \%$ (i.e. $\mathrm{R}$ square= 0.069). The ANOVA in Table 10 shows the Fcal as 14.812 at 0.05 level of significance. By implication, the entry fee accounted for only about $6.9 \%$ of variations in growth of NMOs. Similar to this findings is the work of Jain et al (2015) that discovered that low investment alongside factors such as product quality, ease entry, extra money, freedom are the most effective variables that convince people to be a part of MLM.

The coefficient analysis in Table 11 showed a simple model that expresses how entry fees impact growth of NMOs. The model is mathematically shown below.

$\mathrm{Y}=\mathrm{A}+\mathrm{Bx}+\mu$, where $\mathrm{Y}$ is the growth of NMOs; $\mathrm{A}$ is the constant; $\mathrm{B}$ is the value of coefficient; $\mu$ is the error term. Therefore, GNMOs $=3.030+.256(\mathrm{EF})+.067$. This means that for every $100 \%$ growth of an NMO, entry fee contributed $25.6 \%$.

Table 9: Model summary of entry fee and growth of NMOs

\begin{tabular}{|l|r|r|r|r|}
\hline Model & \multicolumn{1}{|c|}{$\mathrm{R}$} & $\mathrm{R}$ Square & \multicolumn{1}{c|}{$\begin{array}{c}\text { Adjusted R } \\
\text { Square }\end{array}$} & $\begin{array}{l}\text { Std. Error of the } \\
\text { Estimate }\end{array}$ \\
\hline 1 & $.263^{\mathrm{a}}$ & .069 & .064 & .861 \\
\hline
\end{tabular}

a. Predictors: (Constant), Entry fee

Table 10: ANOVA table of entry fee and growth of NMO

\begin{tabular}{|r|r|r|r|r|r|}
\hline \multicolumn{1}{|l|}{ Model } & Sum of Squares & df & Mean Square & F & \multicolumn{1}{c|}{ Sig. } \\
\hline Regression & 10.983 & 1 & 10.983 & 14.812 & $.000^{\mathrm{b}}$ \\
$1 \quad$ Residual & 148.304 & 200 & .742 & & \\
Total & 159.287 & 201 & & & \\
\hline
\end{tabular}

a. Dependent Variable: Growth of NMO

b. Predictors: (Constant), Entry fee 
Table 11: Coefficient table of entry fees and growth of NMOs

\begin{tabular}{|c|c|c|c|c|c|}
\hline \multirow[t]{2}{*}{ Model } & \multicolumn{2}{|c|}{ Unstandardized Coefficients } & \multirow{2}{*}{$\begin{array}{c}\begin{array}{c}\text { Standardized } \\
\text { Coefficients }\end{array} \\
\text { Beta }\end{array}$} & \multirow[t]{2}{*}{$\mathrm{t}$} & \multirow[t]{2}{*}{ Sig. } \\
\hline & B & Std. Error & & & \\
\hline (Constant) & 3.030 & .274 & & 11.043 & .000 \\
\hline Entry Fee & .256 & .067 & .263 & 3.849 & .00 \\
\hline
\end{tabular}

a. Dependent Variable: Growth of NMOs

\section{Conclusion and Recommendations}

Multilevel marketing as a strategy has proved effective for many organizations in the world. The criticisms against MLM is not in the strategy in itself but the companies that adopt the strategy take undue advantage of the opportunities it presents to exploit the public. The entry fee showed a positive relationship in relations to motivation to join MLM given that more than half of the respondents prefer NMOs with low entry fee it was hence found that their cost preference had much effect $(\mathrm{r}=0.328, \mathrm{P}<0.05)$ on their action to join or not to join. Compensation plan was also found to be significantly correlated with motivation to join NMO ( $r=0.327$, $\mathrm{P}<0.05)$. Whilst network entrepreneurs crave for affordable NMOs, they also desire profitable NMOs that guarantee maximum return on investment (ROI). Financial factors were found to motivate network entrepreneurs especially had impacts on the growth of NMOs with variations in entry fees accounting for about $6.9 \%$ variations in growth potential of NMOs and variations in compensation plan accounting for about $10 \%$ variations in growth of NMOs. For every $100 \%$ growth of an $\mathrm{NMO}$, financial factors such as entry fees and compensation plan were found to contribute $25.6 \%$ and $36.2 \%$ respectively relating a significant contribution of these factors to the growth of NMOs. Major recommendations put forward are:

i. Nigerian marketers should be careful about becoming MLM entrepreneurs. It is important to have a profound understanding of the modus operandi of the business before signing up.

ii. Having found that many Nigerians "cut their coats according to their materials", implying that they prefer MLMs that come with affordable entry fees. NMOs can provide variety of plans to suit various socio-economic status to encourage more participation. Beyond the financial compensation, other non-financial compensation should be considered to further serve as motivation given that human needs differ.

iii. Due diligence and in-depth market understanding is needed when designing plans for registration and compensation. Highly motivated network marketers tend to perform more. Proof of earnings compensation proves to be an effective recruiting tool that helps an MLM to grow even faster. 


\section{References}

Abdussalam, F. A., \& Oyebode, A. O. (2016). Marketing Implications of Pricing Models Adoption. International Journal of Entrepreneurship Innovation and Management, 1(1), 17-26.

Adetayo, J. O. (2012). Marketing Management. Lagos: Yemthom Resources Ventures.

Afzal, H., \& Ali, I. (2010). A Study of University Students' Motivation and Its Relationship with Their Academic Performance. International Journal of Business and Management, 5(4), 80-88.

Aggarwal, B., \& Kumar, D. (2014). Multi Level Marketing-Problems \& Solutions. International Journal of Research, 1(6), 76-82.

Akinyi, A. R. (2008). Benefits and Challenges of Multilevel Marketing in Kenya: A Case of Golden Neolife Diamite International Distributors in Nairobi Kenya. University of Nairobi.

Albaum, G., \& Peterson, R. A. (2011). Multilevel (Network) Marketing: An Objective View. The Marketing Review, 11(4), 347-361. https://doi.org/10.1362/146934711X13210328715902

Allport, G. W. (1935). Attitudes. In C. Murchison (Ed.), Handbook of social psychology (pp. 798884). Winchester MA: Clark University Press.

Arya, K., \& Arya, M. (2014). Multilevel Marketing (Mlm). Iinternational Journal of Management and Commerce Innovations, 2(1), 99-102.

Basil, G., Sunday, E. M., Anyadighibe, J., \& Edward, J. (2014). An Empirical Study of the Impact of Non-Store Retailing on Consumers' Satisfaction in Calabar Metropolis, Nigeria. American International Journal of Contemporary Research, 4(12), 46-57.

Bittnerova, M. (2015). Analysis of Work Motivation in Multilevel Marketing. Mendel University in Brno.

Bloch, B. (1996). Multilevel Marketing: What's the Catch? Journal of Consumer Marketing, 13(4), 18-26. https://doi.org/10.1108/07363769610124519

Bogdan, G., \& Aron-Axel, W. (2013). Multi Level Marketing as a Business Model. Marketing of Scientific and Research Organizations, 1(7), 1-20.

Charoenrungsirri, V., \& Oonsuphab, U. (2010). Multi Level Marketing Products in Thailand. Malardalen University.

Choudhary, R., \& Haryana, K. (2013). Multilevel Marketing (MLM) for Socio-Economic Development. International Journal of Reviews, Surveys and Research, 2(1), 1-9.

Chow, S. J., \& Yong, B. C. S. (2013). Secondary School Students' Motivation and Achievement in Combined Science. US-China Education Review, 3(4), 213-228.

Constantin, C. (2009). Multilevel Marketing- A Tool of Relationship Marketing. Bulletin of the Transilvania University of Brasovqqq, 2(51), 31-36.

Coughlan, A. T., \& Grayson, K. (1998). Network Marketing Organizations: Compensation plans, Retail Network Growth, and Profitability. International Journal of Research in Marketing, 15, 401-426.

Dai, F., Teo, S., \& Wang, K. Y. (1995). Identifying and Measuring Motivational Factors in Conducting Network Marketing Business by Chinese Immigrants. Sydney, Australia: University of Technology, Sydney.

Dai, F., Teo, S., \& Wang, K. Y. (2007). Performance of Entrepreneurial Chinese Immigrants in Network Marketing Organisations. Sydney, Australia: University of Technology, Sydney. 
Droney, D. (2015). Networking health: multi-level marketing of health products in Ghana. Anthroplogy and Medicine, 1-13. https://doi.org/10.1080/13648470.2015.1057104

Eccles, J. S., \& Wigfield, A. (2002). Motivational Beliefs, Values and Goals. Annual Review of Psychology, 53, 109-132.

Effiom, L., \& Effiong, F. A. (2015). The Role of Multilevel Marketing (MLM) in Poverty Alleviation in Calabar-Cross River State, Nigeria: A Case Study of Forever Living Product (NIG.) Ltd. Advances in Social Sciences Research Journal, 2(2), 150-163.

Failla, D. (1996). A 45 Second Presentation that can Change your Life: "Own your Own Life." Retrieved from www.soundconcepts.com.

Fish, W. (2010). Philosophy of Perception: A Contemporary Introduction. New York: Routledge.

Franco, W., \& Gonzalez-perez, M. A. (2016). International Expansion Opportunities for Multilevel Marketing via Personal Networks: An Ethnographic Study From Colombia. International Journal of Business and Society, 17(1), 28-46.

Friberg, T. (2008). The Circle of Life in Network Marketing Relationships A Case Study of Tahitian Noni International. Uppsala University.

Gbadeyan, R. A., \& Olorunleke, G. K. (2014). Measuring Consumers' Attitude towards Multilevel Marketing in Ilorin, Nigeria. Ilorin Journal of Management Sciences, 1(1), 42-56.

Haider, S. A., Qureshi, M. M., Pirzada, S. S., \& Shahzadi, I. (2015). A Study of Student's Motivation and its Relationship with their Academic Performance. Journal of Resources Development and Management, 8, 9-18.

Jain, S., Singla, B. B., \& Shashi, S. (2015). Motivational Factors in Multilevel Marketing Business: A Confirmatory Approach. Management Science Letters, 5, 903-914. https://doi.org/10.5267/j.msl.2015.8.006

Jain, V. (2014). 3D Model of Attitude. International Journal of Advanced Research in Management and Social Sciences, 3(3), 1-12.

Joshi, S. V. (2014). Perceptions that Motivate Purchase. International Journal of Engineering, Business and Enterprise Applications, 7(1), 78-82.

Kalra, S., Kondepudi, M., \& Sridharan, A. (2016). Consumer Attitude towards Network Marketing in a Global Scenario. Intercontinental Journal of Marketing Research Review, 4(12), 9-14.

Keep, W., \& Vander Nat, P. J. (2014). Multilevel Marketing and Pyramid Schemes in the United States: An Historical Analysis. Journal of Historical Research in Marketing, 6(4), 1-28.

Keun, N. G. (2004). Participation in Network Marketing Companies: The Motivational Factors That Influence the Part-Time Distributors in Kuching, Sarawak. Universiti Malaysia Sarawak.

Khare, A., \& Verma, P. (2016a). A Study on Unethical Use of Relationships in Multilevel Marketing. International Journal in Management and Social Science, 4(4), 256-261.

Khare, A., \& Verma, P. (2016b). Multilevel Marketing a Way for Achieving Good Social Position by Personality Development. International Journal of Application or Innovation in Engineering and Management, 5(9), 262-270.

Koehn, D. (2001). Ethical Issues Connected with Multi-level Marketing Schemes. Journal of Business Ethics, 29(1), 153-160. 
Kondalkar, V. G. (2007). Orgnazational Behaviour. New Delhi: New Age International Publishers.

Koroth, A. A. (2011). Relevance of Multilevel Marketing in Kerala. University of Calicut.

Koroth, A. A., \& Sarada, A. K. (2012). Significance of Relationship in Multilevel Marketing and its effect on Business Outcome. Journal of Busienss and Management, 3(6), 26-36.

Lai, E. R. (2011). Motivation: A Literature Review. Pearson Research Report.

Lee, K., Lau, T.-C., \& Loi, K.-Y. (2016). Driving Distributors' Satisfaction in Multilevel Marketing ( MLM ) Companies. International Journal of Academic Research in Business and Social Sciences, 6(2), 105-122. https://doi.org/10.6007/IJARBSS/v6-i2/2015

Lee, K., \& Loi, K.-Y. (2016). Towards Satisfying Distributors in Multilevel Marketing Companies. International Journal of Management and Applied Research, 3(1), 48-64. https://doi.org/https://doi.org/10.18646/2056.31.16-004

Legara, E. F., Monterola, C., Juanico, D. E., Litong-palima, M., \& Saloma, C. (2008). Earning Potential in Multilevel Marketing Enterprises. Physica A, 387, 4889-4895. https://doi.org/10.1016/j.physa.2008.04.009.

Leng, N. K. (2015). Factors Influencing Consideration on Multilevel Marketing (MLM) Enrollment. University Tunku Abdul Rahman.

Makni, V. (2015). Public Perceptions towards Network Marketing in Bulgaria. In Proceedings of International Conference Dedicated to the 25th Anniversary of the Specialty International Economic Relations (pp. 1-11). Bulgaria.

Mathews, G. K., Manalel, J., \& Zacharias, S. (2007). Network Marketing: Exploitation of Relationships-Myth or Reality? In International Marketing Conference on Marketing and Society (pp. 159-163).

Miekina, K. (2012). Motivation in Organisations Operating on the Basis of a Multi-Level Marketing System: How do People Motivate Themselves and Others? National College of Ireland.

Mubeen, S., \& Reid, N. (2006). The Measurement of Motivation with Science Students. European Journal of Educational Research, 3(3), 129-144.

Muncy, J. A. (2004). Ethical Issues in Multilevel Marketing: Is it a Legitimate Business or Just Another Pyramid Scheme? Marketing Education Review, 14(3), 47-53.

Oksanen, E. (1999). Structure and Characteristics of Network Marketing Businesses. In Proceedings of the 15th Annual IMP Conference (pp. 1-17). Dublin.

Ong, C., Kiaw, S., \& Run, E. C. De. (2007). Why Malaysians Join and Stay on in a Multi-level Marketing Company. The Icfai Journal of Services Marketing, 5(4), 37-52.

Otokiti, S. O. (2010). Contemporary Issues and Controversy in Research Methodology. Dubai: Dubai Printing Press.

Peklaj, C., \& Levpuscek, M. P. (2006). Students' motivation and academic success in relation to the quality of individual and collaborative work during a course in educational psychology. In 31st Annual Association of Teacher Education in Europe Conference (pp. 147161).

Pickens, J. (2005). Attitudes and Perceptions of Individuals. In N. Borkowski (Ed.), Organizational Behavior in Health Care (pp. 43-76). New York: Jones and Bartlett Publishers. 
Rani, R., \& Kumar, N. (2013). Multilevel Marketing versus Pyramid Schemes. International Monthly Refereed Journal of Research in Management and Technology, 2, 40-46.

Reavis, A. (2014). The Misunderstanding of Multi-Level Marketing. Liberty University.

Rezvani, M., Ghahramani, S., \& Haddadi, R. (2017). Network Marketing Strategies in Sale and Marketing Products Based on Advanced Technology in Micro-Enterprises. International Journal of Trade, Economics and Finance, 8(1), 32-37. https://doi.org/10.181.78/ijtef.2017.8.1.535

Sekeran, U. (2003). Research Methods for Business: A Skill Building Approach. (J. Marshall and P. McFadden, Eds.) (4th Ed). United States of America: John Wiley and Sons Inc.

Tamang, N. B. (2008). Role of Network Marketing In Non Timber Forest Products (NTFPS) Promotion: A case study of easy multitrade international (P) Ltd, Nepal. Tribhuvan University.

Taylor, J. M. (2011). Multi-level Marketing Unmasked -The Case Against Multilevel Marketing as an Unfair and Deceptive Practice. United States of America.

Tepede, D. (2011, November). Multilevel Marketing Creates New Millionaires in Nigeria. Obtainer Worldwide, 110-112. Retrieved from www.dipotepede.org.

Vahidi, T. (2016). An Examination on Age Groups and Network Marketing: The Opportunities and Challenges. Research \& Reviews : Journal of Social Sciences, 2(2), 1-4.

Vander Nat, P. J., \& Keep, W. W. (2002). Marketing Fraud: An Approach for Differentiating Multilevel Marketing from Pyramid Schemes. Journal of Public Policy and Marketing, 21(1), 139-151.

Wigren, J. (2017). Leadership challenge -An Approach to Professional Group Management in Network Marketing. Turku University of Applied Sciences.

Worre, E. (2015). GO PRO: 7 steps to becoming a network marketing professional. USA.

Yen, J., Chen, M., \& Chen, Y. (2008). The Study of Direct Selling Management Strategies: An Example of the Avon Cosmetics Company in Taiwan. Journal of International Management Studies, (February), 214-227.

Yin, L. K. (2015). Determinants of Distributor Satisfaction in Multilevel Marketing Companies. University Tunku Abdul Rahman. 